INTERNATIONAL JOURNAL OF MULTidisciplinARY RESEARCH AND ANALYSis

ISSN(print): 2643-9840, ISSN(online): 2643-9875

Volume 05 Issue 01 January 2022

DOI: 10.47191/ijmra/v5-i1-02, Impact Factor: 6.072

Page No.- $13-17$

\title{
The Borrowing Processes of Thai Language in Patani Malay Dialect in Thailand
}

\author{
Abdonloh Khreeda-Oh ${ }^{1}$, Hishamudin Isam ${ }^{2}$, Mashetoh Abd Mutalib ${ }^{3}$ \\ ${ }^{1}$ Faculty of Humanities and Social Sciences, Prince of Songkla University, Pattani Campus \\ ${ }^{2,3}$ School of Languages, Culture and Philosophy, College of Arts and Sciences, Universiti Utara Malaysia
}

\begin{abstract}
This study concerns with the processes borrowing Thai language (TL) words in Patani Malay Dialect (PMD) from the perspective of Sociolinguistics. The main objective of this study is to see how the processes happen from TL to PMD. The research data for TL loanwords in PMD are obtained from written and spoken language while the data from TL itself are obtained from written materials. Attention towards the processes of TL loanwords in PMD is in regard with the study about similarities between TL and Malay language (ML) through two important processes; importation and substitution. Indirectly this study also touched on the influence of TL which has an important role to the lexical elements of PMD. In addition to the elaboration of the borrowing process, an analysis was also carried out on the process of changing TL loanwords in PMD in terms of phonology involving vocal and consonant changes using descriptive approaches. Finally, the findings showed that apart from direct borrowing from TL, PMD also adapts the loanwords according to the existing system in PMD. Even from the borrowing elements themselves, it is found that there are words considered to come from the same family while some are borrowed from other languages.
\end{abstract}

KEYWORD: Patani Malay Dialect, Thai Language, Borrowing, Loanwords, Importation, Substitution.

\section{INTRODUCTION}

Language is part of the cultural elements which is a common property of a group of people descended through its descendants, and should be transformed towards progress (Asmah Haji Omar, 1985: 3). For the purpose of language enrichment, a society must be open to new inclusions without compromising existing values in society. The inclusion of these new values is known as borrowing or loaning (Nik Safiah Karim, 1996: 72).

Language borrowing is resulted from language collision that has caused the entry of foreign elements into a certain language (Zaharani Ahmad, et.al, 2011: 14). According to Asmah Haji Omar (1995: 5-7), Malay language (ML) has received has received an influence from Sanskrit, followed by Arabic in the $10^{\text {th }}$ century, and in the present, widely influenced by English due to the development of science and technology. Besides that, there are also other languages that have given an impact to ML like Javanese, Tamil, Chinese, Portuguese, Dutch and Persian (Zaharani Ahmad, et.al, 2011: 14).

In Thailand, standard Thai language (TL) has also contributed to the development of ML vocabulary treasures especially the Patani Malay dialect (PMD) spoken in Southern Thailand which covers the regions of Pattani, Yala and Narathiwat (Faiz Awae, 2015: 104). This is also inclusive of certain districts in Songkhla province such as Chana, Thepa, Nathawi, Sabayoi and Sadao (Ruslan Uthai, 2011: 20). The condition of the Malay community due to the pressures of the assimilation policy from the Thai government shows the development of PMD in facing changes in accordance with the era (Hara Shintaro, 2001: 175). Hence, the discussions in this study focused on the identification of TL loanwords in PMD as well as about the borrowing processes by explaining the appropriateness of language in the loanwords.

\section{RESEARCH OBJECTIVE}

This study is aimed at reviewing the process of TL loanwords in PMD. Indirectly, it will also identify some TL loanwords in PMD. Besides that, it will touch on the types and categories of TL loanwords in ML that are able to show the development of PMD spoken at the present. Further aspects to be studied include research and analysis of loanword changes in PMD from TL, such as phonological changes and changes in meaning. However, the change in meaning will only be mentioned at a glance. 


\section{The Borrowing Processes of Thai Language in Patani Malay Dialect in Thailand}

\section{THEORETICAL FRAMEWORK}

The study belongs to Sociolinguistics that examined TL loanwords in PMD spoken in the region of Southern Thai border. In fact, if two or more languages are used in the same society, then there is a clash of languages (Amran Halim, 1980: 22). As such, frequent relationships or influences are symptoms of borrowing.(Abdullah Hassan, 1974: 216-217).

In terminology, one way to form a new word or term is through the borrowing process, either from a cognate language or a non-cognate language (Haugen, 1953: 363). Thus, word borrowing is a process that involves re-earning the original pattern or model of the borrower's language. This study is undergone based on a theory proposed by Haugen (1950) who said that there are two important processes in language borrowing which are the process of importation and the process of substitution. The former process happens when the results of the loanwords are similar to the native language once the speaker receives the words. Meanwhile, the latter process simply means new words are invented. This process happens only if the results of the loanwords are derived from imperfect source language. Consequently, the speakers would substitute those words by matching and appropriating from the source language with the existing pattern in their native language.

In addition, Haugen (1950) has also divided borrowing words into three main types which are loanwords, loan blends and loan translations. Loanwords are words that have undergone a full morphemic importation while loan blends are words that are modified a bit on its phonemic in which some part are imported from a foreign language and some are original morphemes. Loan translations are words that are borrowed from other languages and translated into the recipient's language. These loan processes and forms will be applied to TL loanwords in PMD according to the appropriateness of the language.

\section{RESEARCH FINDINGS}

The results of a study conducted in Pattani province has found that the processes of TL loanwords in PMD existed, and can be categorized into several types. There are also several factors contributed to the occurrence of these processes which are the needs to use new concepts and the efforts to achieve language modernisation.

Based on the study, there are two types of loaning process which are the process of importation and the process of substitution. The first process has resulted in the creation of two loaning processes: loanwords and loan blends. Loanwords occurred in PMD are caused by the lack of certain terms in particular fields in PMD. Hence, it is found that loanwords used in PMD have similar features or near similar with the original pronunciation in TL as listed in the examples:

\begin{tabular}{|c|c|c|c|c|c|}
\hline \multirow[b]{2}{*}{1.} & \multirow[b]{2}{*}{ ดัง } & \multirow{2}{*}{$\begin{array}{r}\mathrm{TL} \\
\text { / dan / }\end{array}$} & \multicolumn{2}{|c|}{ PMD } & \multirow{2}{*}{$\begin{array}{l}\text { ML } \\
\text { famous }\end{array}$} \\
\hline & & & / dan / & $=$ & \\
\hline 2. & แก้ & / ke: / & / kë / & $=$ & correct \\
\hline 3. & ลา & / la: / & / la / & $=$ & holiday \\
\hline 4. & ป้าย & / pa:y / & / pay / & $=$ & label \\
\hline 5. & ติ & / tip / & $/ \operatorname{tip} /$ & $=$ & criticize \\
\hline 6. & โต๊ะ & / to? / & / tö? / & $=$ & table \\
\hline
\end{tabular}

Besides that, there are also loanwords from TL that have been assimilated with the features of PMD phonology. Yet, they still have the TL features in them as shown in the examples below:

$$
\text { TL }
$$

1. ปลอม

2. จำเป็น

3. เจ้า

4. กำนัน

5. พอ

6. รอด
ML

/ plo:m /
/ campen /
/ ca:w /
/ kamnan /
/ pho: /
/ ro:d /

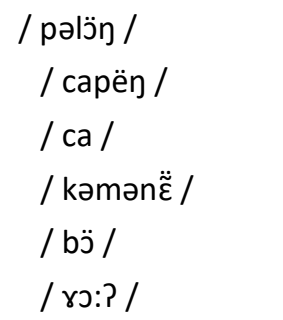

$\begin{array}{ll}= & \text { fake } \\ = & \text { have to } \\ = & \text { Buddhist monk } \\ = & \text { village head } \\ = & \text { sufficient } \\ = & \text { capable of }\end{array}$

Loan blends occurred due to the processes of importation and substitution, and a combination between PMD and TL. Words in TL that are brought in and combined with PMD consist of one-layer word + one-layer word and one-layer word + complex word. As a result, the words are complex that might consist of compound words or phrases. Some examples of loan blends are illustrated below: 
The Borrowing Processes of Thai Language in Patani Malay Dialect in Thailand

\begin{tabular}{|c|c|c|c|c|}
\hline No. & $\begin{array}{l}\text { Language / } \\
\text { Dialect }\end{array}$ & PMD words & TL words & ML \\
\hline 1. & $\begin{array}{l}\text { TL } \\
\text { PMD } \\
\end{array}$ & $\begin{array}{l}\text { / sur:a / } \\
\text { / bajt / }\end{array}$ & $\begin{array}{l}\text { / ki:la: / } \\
\text { / kila / }\end{array}$ & shirt + sports $=$ sports shirt \\
\hline 2. & $\begin{array}{l}\text { TL } \\
\text { PMD }\end{array}$ & $\begin{array}{l}\text { / yib / } \\
\text { / jəрt? / }\end{array}$ & $\begin{array}{l}\text { / thaha:n / } \\
\text { / tahan / }\end{array}$ & invite + army $=$ choosing army \\
\hline 3 & $\begin{array}{l}\text { TL } \\
\text { PMD }\end{array}$ & $\begin{array}{l}/ / p^{h} \supset: / \\
/ \text { bz̈ / }\end{array}$ & $\begin{array}{l}\text { / di: / } \\
\text { / mölë? / }\end{array}$ & enough + just nice $=$ sufficient \\
\hline 4. & $\begin{array}{c}\text { TL } \\
\text { PMD }\end{array}$ & $\begin{array}{l}\text { / yə̈:m / } \\
\text { / jə̈n / }\end{array}$ & $\begin{array}{l}\text { / } \mathrm{p}^{\mathrm{h}} \ddot{\varepsilon}: / \\
\text { / alə̈h / }\end{array}$ & willing + lose $=$ admit to losing \\
\hline 5. & $\begin{array}{l}\text { TL } \\
\text { PMD }\end{array}$ & $\begin{array}{l}\text { / fay / } \\
\text { / apł / }\end{array}$ & $\begin{array}{l}\text { / fa: / } \\
\text { / pëfa / }\end{array}$ & $\begin{array}{l}\text { fire }+ \text { sky }=\text { electric } \\
\text { fire }+ \text { electric = electric }\end{array}$ \\
\hline 6. & $\begin{array}{l}\text { TL } \\
\text { PMD }\end{array}$ & $\begin{array}{l}\text { /bi:a / } \\
\text { / duwi? / }\end{array}$ & $\begin{array}{l}\text { /li:an / } \\
\text { / biyalłyan / }\end{array}$ & $\begin{array}{l}\text { money }+ \text { spend }=\text { allowance } \\
\text { money }+ \text { allowance }=\text { allowance }\end{array}$ \\
\hline
\end{tabular}

In the process of substitution for loan translations, a certain word or phrase in TL is substituted with the existing form in PMD in which it means that only the structure or the meaning is borrowed. Loan translations from TL are a combination of new morphemes in PMD, and the examples are illustrated below:

\begin{tabular}{|c|c|c|c|c|}
\hline No. & Language / Dialect & $\begin{array}{l}\text { Source } \\
\text { words }\end{array}$ & $\begin{array}{l}\text { Source } \\
\text { words }\end{array}$ & ML \\
\hline 1. & $\begin{array}{l}\text { TL } \\
\text { PMD }\end{array}$ & $\begin{array}{l}/ \mathrm{do:k} / \\
\text { / duwi? / }\end{array}$ & $\begin{array}{l}\text { / bi:a / } \\
\text { / bunכ̈ / }\end{array}$ & $\begin{array}{l}\text { flower }+ \text { money }=\text { interest }(\text { finance }) \\
\text { money }+ \text { flower }=\text { interest (finance) }\end{array}$ \\
\hline 2. & $\begin{array}{l}\text { TL } \\
\text { PMD }\end{array}$ & $\begin{array}{l}/ \log / \\
/ \text { ttrön }\end{array}$ & $\begin{array}{l}\text { / thun / } \\
\text { / möda / }\end{array}$ & give away + capital = invest \\
\hline 3. & $\begin{array}{l}\text { TL } \\
\text { PMD }\end{array}$ & $\begin{array}{l}\text { / so:b / } \\
\text { / pë?sö / }\end{array}$ & 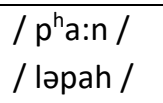 & $\begin{array}{l}\text { examination }+ \text { passed }= \\
\text { passed in examination }\end{array}$ \\
\hline 4. & $\begin{array}{l}\text { TL } \\
\text { PMD }\end{array}$ & $\begin{array}{l}\text { /ok / } \\
\text { / patöh / }\end{array}$ & $\begin{array}{l}\text { / hak / } \\
\text { / dad / }\end{array}$ & $\begin{array}{l}\text { chest }+ \text { break }=\text { heartbroken } \\
\text { break }+ \text { chest }=\text { heartbroken }\end{array}$ \\
\hline 5. & $\begin{array}{l}\text { TL } \\
\text { PMD }\end{array}$ & $\begin{array}{l}\text { / ha: / } \\
\text { / cart / }\end{array}$ & $\begin{array}{l}\text { / si:an / } \\
\text { / sə̈rz̈ / }\end{array}$ & search for + voice = campaigning \\
\hline 6. & $\begin{array}{l}\text { TL } \\
\text { PMD }\end{array}$ & $\begin{array}{l}\text { / ri:an / } \\
\text { / paji / }\end{array}$ & $\begin{array}{l}\text { / to: / } \\
\text { / h甘bön / }\end{array}$ & $\begin{array}{l}\text { study }+ \text { connect }=\text { further study } \\
\text { study }+ \text { connect }=\text { futher study }\end{array}$ \\
\hline
\end{tabular}

Based on the processes resulted from TL loanwords in PMD, this study also examines the phonological changes from the loanwords that involve vocal sounds and consonants. However, a vivid change can bee seen in the plosive sound. In this case, all plosive consonants appeared at the end range of the TL loanwords in PMD will be substituted with the sound of a glottis halt / ? /. This is likewise apparent in the plosive sound that occurred in consonant stanzas that will experience the same occurrence. Generally, the symptom of glottis appeared in PMD as well including the East Coast dialects of Kelantan and Terengganu in Malaysia (Asmah Haji Omar, 1995: 266). However, the changes in the middle range of the words only happen at the closure of the first syllables. Look at the examples illustrated below:

TL

PMD

ML

$\begin{array}{llllll}\text { 1. จบ } & \text { / co:b / } & \text { / cö? / } & = & \text { finish } \\ \text { 2. } & \text { ชุด } & / c^{h} u d / & / \text { tr? } / & = & \text { uniform } \\ \text { 3. } & \text { บุก } & \text { / buk / } & / \text { bt? / } & = & \text { raid } \\ \text { 4. เหตุ } & \text { / he:t / } & / \text { hë? / } & = & \text { about }\end{array}$

In addition, another change that is interesting about TL loanwords in PMD is the elimination of aspiration. This process happens when TL loanwords have aspiration features that become consonants without aspiration in PMD. The elimination of aspiration plosive consonants consists of $/ \mathrm{p}^{\mathrm{h}} / \mathrm{l} / \mathrm{t}^{\mathrm{h}} /$ and $/ \mathrm{k}^{\mathrm{h}} /$ in which each of them will produce two new consonants whereby / $\mathrm{p}^{\mathrm{h}} /$ will 


\section{The Borrowing Processes of Thai Language in Patani Malay Dialect in Thailand}

produce new consonants / $\mathrm{p} /$ and $/ \mathrm{b} /$. As for $/ \mathrm{t}^{\mathrm{h}} /$, it will produce new consonants $/ \mathrm{t} /$ and $/ \mathrm{d} / ;$ and $/ \mathrm{k}^{\mathrm{h}} /$ will produce new consonants $/ \mathrm{k} / \mathrm{dan} / \mathrm{g} /$. Besides that, there is also elimination of aspiration fricative consonant $/ \mathrm{c}^{\mathrm{h}} /$ that will produce two new consonants / $\mathrm{c} /$ and $/ \mathrm{j} /$. Below are the examples related to this explanation :

TL

1. ผู้แทน

2. พอดี

3. โทรศัพท์

4. ทหาร

5. ทัน

6. ค่อย

7. คอย

8. คุก

9. ชะแลง

10. ชาย
/ $p^{h} u: t^{h} \varepsilon: n /$

/ $\mathrm{p}^{\mathrm{h}} \mathrm{o}$ :di: /

/ $\mathrm{t}^{\mathrm{h}} \mathrm{o}:$ rasap /

PMD

/ thaha:n /

$/ \mathrm{t}^{\mathrm{h}}$ an /

/ $k^{\text {hoy } / ~}$

/ $k^{h}$ o:y /

/ $k^{\text {h } u k ~ / ~}$

/ charlen /

/ cha:y /
ML

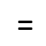

Parliament)

medium

/ bว̈mölë? /

/ törösa? / =

/ tahan $/=\quad$ army

$/ \mathrm{d} \ddot{\tilde{\varepsilon}} /=$

/ köhว̈ / =

$/ \mathrm{k} / \mathrm{l}=$ wait

/gö? / = prison

/ cëlën / = lever

/ c $/$ = grandfather

Another process that frequently happens in TL loanwords in PMD is the process of co-articulation. However, based on the collected data it is found that there are several TL loanwords in PMD that do not conform to this process. This issue might happen due to the words being newly borrowed and used in PMD. Look at the examples below:

\section{a) Articulation process}

TL

1. สยาม

2. ศาล

3. สตางค์
PMD

/ sayam /
/ sa:n /
/ sata:n /

/ sły $\ddot{\tilde{\varepsilon}} /$

/ s $\ddot{\tilde{\varepsilon}}$ /

/ sət $\ddot{\varepsilon}$ /
ML

$=$ Siam

$=$ court

$=\quad$ Thai currency

\section{b) Nasal retention}

BT

1. ต้มยำ

2. การบ้าน

3. นายช่าง
DMP

/ tomyam /

/ ka:nba:n /

/ na:ychan /
BMS

$\begin{array}{lll}/ \text { tönyam / } & = & \text { tom yam } \\ / \text { kanban } / & = & \text { homework } \\ / \text { nëcan } / & = & \text { handyman }\end{array}$

Another process that frequently happens in TL loanwords in PMD is the process of monophthongization which means that the diphthong elements are changed into monophthong. In this case, the process of monophthongization can be divided into two types, which are:

1. Dropping one of the diphthongs, and

2. Dissolving diphthong elements and producing another sound.

The examples are as below:

TL

1. เจ้า

2. ทนาย

3. ค่อย

4. คาย

5. ใบเสร็จ

6. นายบ้าน
PMD

/ ca:w /
/ thana:y /
/ khəy /
/ kha:y /
/ bayset /
/ na:yba:n /

/ tö?ca / = Buddhist head monk

/ tö?na /=

advocates

/ köhว̈ /

/ këhë? / =

to express

$/$ bësë? $/=\quad$ receipt

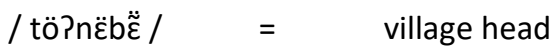

Apart from borrowing elements, it is found that there are words between TL and PMD in which the forms and meanings are similar with each other. Basic words like / ta: / "mata" (eyes), / kha: / "kaki" (feet), / phet / "pedas" (spicy), / mot / "semut" 


\section{The Borrowing Processes of Thai Language in Patani Malay Dialect in Thailand}

(ant) and so on are believed to derived from the same source which is Malay language (Hara Shintaro, 1998: 445). Based on the study made, and the data collected, the similarities occur because both TL and ML are located under the same phylum; the Austric phylum (C.A.Mees, 1967: 12). Hence, it is assumed that those words that have similarities among each other belong to the same parent of language because they are also apparent in $\mathrm{ML}$ and Malay dialects. Some of the words are illustrated below:

TL

1. แปลก
2. ตวง
3. จิ้งจก
4. จูบ
5. สกัด
6. รัง

PMD

$$
\begin{aligned}
& \text { / ple:k / } \\
& \text { / tua:n / } \\
& \text { / cincok / } \\
& \text { / cu:p / } \\
& \text { / sakad / } \\
& \text { / ran / }
\end{aligned}
$$

\section{ML}

$\begin{array}{ll}= & \text { absurd } \\ = & \text { pour } \\ = & \text { lizard } \\ = & \text { kiss } \\ = & \text { ban } \\ = & \text { nest }\end{array}$

Indeed, there are many words in TL that are equal in meanings and pronunciation like $\mathrm{ML}$ to an extent that it is impossible to say that those similarities are resulted from language borrowing. However, problems might arise when the direction of the borrowing is uncertain as there is no clear differentiation feature. Therefore, it is likely that these features show kindred characteristics between ML and TL. Nonetheless, a more detailed study needs to be carried out regarding this issue.

\section{CONCLUSION}

From the study conducted at Pattani province, TL that exists today is regarded as the dominant language that has a wide influence and roles on PMD. This is due to the urgent need for the use of new concepts and the efforts of language modernization in accordance with the eras. In addition, due to the increasingly absorbing TL into speech and the use of PMD, especially among the younger generation, TL is widely used alternately with PMD. Even though there are many TL loanwords in PMD, most of the words are made appropriate to be used so that the speakers of PMD will find it easy to pronounce.

\section{REFERENCES}

1) Abdullah Hassan . (1974). The Morphology of Malay, Kuala Lumpur: Dewan Bahasa dan Pustaka.

2) Amran Halim. (1980). "Fungsi dan Kebudayaan Bahasa Indonesia" dalam Politik Bahasa Nasional, Jakarta: Department Pendidikan dan Kebudayaan, halaman 20-28.

3) Asmah Haji Omar. (1985). Susur Galur Bahasa Melayu, Kuala Lumpur: Dewan Bahasa dan Pustaka.

4) Asmah Haji Omar. (1995). Rekonstruksi Fonologi Bahasa Melayu Induk, Kuala Lumpur: Dewan Bahasa dan Pustaka.

5) C.A.Mees. (1967). Ilmu Perbandingan Bahasa-bahasa Austronesia, Kuala Lumpur: Art Printing Works.

6) Faiz Awae. (2015). Fungsi alih kod dalam komuniti masyarakat Melayu Patani, Jurnal Melayu, 14 (1), $103-119$.

7) Haugen, E. (1950). "The Analysis of Linguistics Borrowing” dalam Language, Vol. 26, dicetak semula dalam The Ecology of Language, 1972, Stamford: University of Stamford Press.

8) Haugen, E. (1953). The Norwegian Language in America a Study in Bilingual Behavior, Vol. II, Philadelphia: University of Pensylvania Press.

9) Nik Safiah Nik Abdul Karim, Farid M. Onn, Hashim Haji Musa, Abdul Hamid Mahmood. (1996). Tatabahasa Dewan Edisi Baharu, Kuala Lumpur: Dewan Bahasa dan Pustaka.

10) Ruslan Uthai. (2011). Keistimewa dialek Melayu Patani. Bangi: Penerbit Universiti Kebangsaan Malaysia.

11) Shintaro, Hara. (1998). “Etimologi dalam Pengajian Melayu: Satu Cadangan Berdasarkan Perbandingan Bahasa Melayu dengan Bahasa Thai" dalam Pengajian Bahasa Melayu Memasuki Alaf Baru, diselenggarakan oleh Sanat Md. Nasir dan Rogayah A. Razak, Kuala Lumpur: Akademi Pengajian Melayu, Universiti Malaya.

12) Shintaro, Hara. (2001). Perbandingan arah perkembangan bahasa Melayu di Malaysia dan Thailand. Tesis M.A. Kuala Lumpur: Akademi Pengajian Melayu, Universiti Malaya.

13) Zaharani Ahmad, Nor Hashimah Jalaluddin, Fazal Muhamed Muhamed Sultan, Harishon Razi \& Mohd Shabri Yusof. (2011). Pemerkasaan jati diri bahasa Melayu: isu penyerapan kata asing. Jurnal Melayu, 6, 13-27. 